Winter 2011

\title{
Respect My Authority: Analyzing Claims of Diminished U.S. Supreme Court Influence Abroad
}

Aaron B. Aft

Indiana University Maurer School of Law

Follow this and additional works at: https://www.repository.law.indiana.edu/ijgls

Part of the Courts Commons, and the International Law Commons

\section{Recommended Citation}

Aft, Aaron B. (2011) "Respect My Authority: Analyzing Claims of Diminished U.S. Supreme Court Influence Abroad," Indiana Journal of Global Legal Studies: Vol. 18 : Iss. 1 , Article 17.

Available at: https://www.repository.law.indiana.edu/ijgls/vol18/iss1/17

This Note is brought to you for free and open access by the Law School Journals at Digital Repository @ Maurer Law. It has been accepted for inclusion in Indiana Journal of Global Legal Studies by an authorized editor of Digital Repository@Maurer Law. For more information, please contactrvaughan@indiana.edu.

\section{$\Psi$}

JEROME HALL LAW LIBRARY

INDIANA UNIVERSITY

Maurer School of Law
Bloomington 


\title{
Respect My Authority: Analyzing Claims of Diminished U.S. Supreme Court Influence Abroad
}

\begin{abstract}
AARON B. AFT*
ABSTRACT

This paper critiques the argument that the U.S. Supreme Court is losing influence among national and constitutional courts worldwide as a result of its nonparticipation in the emerging judicial globalization. It does so, inter alia, by reviewing two examples of how U.S. authority is cited abroad, and concludes that arguments of diminished influence appear overstated, and that changes in U.S. judicial influence are not likely due to attitudes toward citation of foreign law.
\end{abstract}

\section{INTRODUCTION}

According to some observers, the legal influence of the United States in the world is waning. ${ }^{1}$ Where once the world looked to the U.S. Supreme Court as a guiding light, now foreign courts are increasingly disinterested in what our nine Justices have to say. "One of our great exports used to be constitutional law," contends Anne-Marie Slaughter; "we are losing one of the greatest bully pulpits we have ever had." Some commentators view this trend as disturbing evidence that the United States is losing its voice in an emerging international and transnational legal dialogue. ${ }^{4}$ This does not appear to be a temporary

* Executive Online Editor, Indian Journal of Global Legal Studies; J.D. Candidate, 2011, Indiana University Maurer School of Law; B.A., 2004, Indiana University. I would like to thank Professors Alfred C. Aman, Jr., Luis Fuentes-Rohwer, and Peter Hook for their guidance and support. Thanks also to my family for their help, without which this paper would not have been written.

1. Adam Liptak, U.S. Court, a Longtime Beacon, Is Now Guiding Fewer Nations, N.Y. TIMES, Sept. 18, 2008, at A1.

2. See id.

3. Id. (quoting Anne-Marie Slaughter).

4. E.g., Rebecca A. Lefler, Note, A Comparison of Comparison: Use of Foreign Case Law as Persuasive Authority by the United States Supreme Court, the Supreme Court of

Indiana Journal of Global Legal Studies Vol. 18 \#1 (Winter 2011)

(C) Indiana University Maurer School of Law 
fad: the U.S. Supreme Court's fading relevance in this global judicial dialogue is seen as a consequence of globalization. ${ }^{5}$ In sum, "Judges are globalizing," 6 "[c]ourts are talking to one another all over the world,"7 and the United States is "out of step with [this] international mainstream."8

There is empirical evidence offered to support this proposition. For example, the New York Times found that the rate of citation to the U.S. Supreme Court by the Supreme Court of Canada from 2002 to 2008 fell by fifty percent as compared to the number of citations from 1990 to $2002.9^{9}$ Particularly in human rights cases, foreign courts are now more likely to cite the European Court of Human Rights than the U.S. Supreme Court. ${ }^{10}$ Politics is one explanation offered for this trend.11 For instance, Thomas Ginsburg views the waning influence of the U.S. Supreme Court as the result of unpopular foreign policies undermining U.S. standing abroad. ${ }^{12}$ Another reason suggested is that justices from high courts desire to give as well as take. ${ }^{13}$

There are also admonitions that the United States ought to take part in the emerging international judicial dialogue. Diane Amann calls for "[j] ustices both to articulate when it is appropriate to look to external sources and to set forth a framework for consultation." 14 Law student Cody Moon argues that the position of the United States "in the

Canada, and the High Court of Australia, 11 S. CAL. INTERDISC. L.J. 165, 167 (2001) (contending that by rejecting comparative constitutional analysis, the United States loses out on the wisdom transnational judicial dialogue advances, and the opportunity to contribute and influence this dialogue).

5. See generally Anne-Marie Slaughter, Judicial Globalization, 40 VA. J. INT'L L. 1103 (2000) (describing modes of judicial interaction that collectively describe how judiciaries have been globalizing).

6. Id. at 1123 .

7. Anne-Marie Slaughter, A Typology of Transjudicial Communication, 29 U. RICH. L. REV. 99, 99 (1994).

8. Sujit Choudhry, Globalization in Search of Justification: Toward a Theory of Comparative Constitutional Interpretation, 74 IND. L.J. 819, 820 (1999).

9. Liptak, supra note 1.

10. Id. (attributing the statement to Harold Koh, the Dean of the Yale School of Law).

11. Id. (suggesting that foreign high courts are often more liberal than the Rehnquist and Roberts Courts, and as a result, are more likely to cite one another).

12. Id. (quoting Thomas Ginsburg, professor of comparative and international law at the University of Chicago).

13. See, e.g., Claire L'Heureux-Dubé, The Importance of Dialogue: Globalization and the International Impact of the Rehnquist Court, 34 TULSA L.J. 15, 17 (1998) (stating that "the process of international influence has changed from reception to dialogue."); Liptak, supra note 1 (quoting Israeli Supreme Court Justice Aharon Barak and Australian High Court Justice Michael Kirby).

14. Diane Marie Amann, International Law and the Rehnquist-Era Reversals, 94 Geo. L. J. 1319, 1319 (2006). 
world legal community requires the United States Supreme Court to engage in the comparative constitutional dialogue."15 Law student Rebecca Lefler speaks of the potential benefits that might flow from engaging in this judicial dialogue. ${ }^{16}$ Claire L-Heureux-Dubé cites the lack of participation in this dialogue as an important reason for the U.S. Supreme Court's waning influence. ${ }^{17}$

These assertions are hard to test. The purpose of this Note is to evaluate the claim that the U.S. Supreme Court is losing influence among other national and constitutional courts, and the explanations offered for this trend. Through the following discussion, this Note shows that the available data does not compel the conclusion that U.S. judicial influence is declining. The complete picture of the Supreme Court's influence on foreign courts is complex, and while there is certainly some support for the claims of diminished influence, there are reasons to be skeptical of the explanations for this trend identified above.

The discussion in Part I proceeds in three sections. The first section describes the U.S. Supreme Court's practice of citing to foreign precedent and the robust, continuing debate on this subject within the United States. The second section surveys the extent to which U.S. Supreme Court precedent is used abroad.18 Because transnational judicial dialogue need not be confined to written judicial opinions, the third section provides a survey of the "informal" contacts-interactions beyond the context of adjudicating cases-between U.S. Supreme Court Justices and their colleagues and counterparts around the world. This section acknowledges that an empirical citation study alone, though important, is likely insufficient to fully capture the possible influence of the U.S. Supreme Court abroad. ${ }^{19}$ Part II then evaluates the claim of

15. Cody Moon, Note, Comparative Constitutional Analysis: Should the United States Supreme Court Join the Dialogue?, 12 WASH. U. J.L. \& POL'Y 229, 246 (2003).

16. See, e.g., Lefler, supra note 4, at 190-191 ('Learning from other countries' experiences can only enhance and clarify what is best within our own legal system; ignoring the decisions and opinions from around the world is turning our backs on a valuable jurisprudential resource.").

17. L'Heureux-Dubé, supra note 13, at 37 ("[T] he failure of the United States Supreme Court to take part in the international dialogue among the courts of the world, particularly on human rights issues, is contributing to a growing isolation and diminished influence.").

18. As will be discussed below, there is relatively little data exclusively on the U.S. Supreme Court. To supplement this deficiency, I will also discuss data on citation to U.S. courts in general, while noting the percentage of such citations that refer to the Supreme Court in particular.

19. In other words, the specific influence of a given case or a given court may only be measured by way of counting citations and references. However, the possibility that interactions with fellow jurists from around the world will, if only by "osmosis," exert some influence on the U.S. Justices is too plausible to simply discount. Therefore, the final 
diminishing U.S. influence in light of Part I, critiques the elucidations articulated by Slaughter, Ginsburg, Choudhry, and others identified in the Introduction, and provides alternative explanations for trends in citation to U.S. authority abroad. This project is not exhaustive but rather a first step. The goal is to introduce an element of verifiable metrics into a conversation that has been dominated by anecdotal evidence in the hope that further empirical study will be conducted.

\section{Measuring the U.S. Supreme CourT's Influence Abroad}

The influence the U.S. Supreme Court supposedly once wielded, and supposedly is now losing, is most often cast as the preeminence of U.S. jurisprudential ideas within the emerging global judicial community. ${ }^{20}$ The dialogue that characterizes contemporary transnational judicial interaction represents a paradigm shift from the top-down dictation of the past to an exchange among peers. ${ }^{21}$ Therefore, to determine the extent to which ideas are exchanged, we must first determine what methods of exchange are used by the global judicial community. This requires consideration of the role of foreign jurisprudential ideas in the United States and the influence of U.S. Supreme Court jurisprudential ideas abroad. Dialogue, after all, is a give and take, ${ }^{22}$ and it is only logical to examine both sides of the conversation.

This paper approaches the issue primarily by analyzing the practice of citation and reference to foreign precedent by national Supreme Courts. ${ }^{23}$ Citations are more than mere footnotes. They "mean[]

section of Part I acknowledges this potential source of otherwise difficult-to-measure influence by and on the jurisprudence of U.S. Supreme Court Justices.

20. See Slaughter, supra note 5, passim; see also Hannah Buxbaum, From Empire to Globalization... and Back? A Post-Colonial View of Transjudicialism, 11 IND. J. GLOBAL LEGAL STUD. 183, 184 (2004) (describing the cross-fertilization that characterizes the exchange of legal ideas in the emerging global judicial community); L'Heureux-Dubé, supra note 13 , at 17 .

21. Indeed, it is the two-way street that distinguishes contemporary judicial dialogue and globalization from the previous force pushing judicial interaction-imperial domination and the supremacy of imperial courts to those of local jurisdictions. For discussion of this difference, see Buxbaum, supra note 20, at 185.

22. As noted above, see, for example, L'Heureux-Dubé, supra note 13, at 17 (stating that "the process of international influence has changed from reception to dialogue."); Liptak, supra note 1 (quoting Israeli Supreme Court Justice Aharon Barak and Australian High Court Justice Michael Kirby).

23. For the purposes of this paper "foreign law," "foreign precedent," and "foreign case law" are synonymous. That is, the phrase "foreign precedent" refers to published judicial opinions of courts outside the United States, or from a jurisdiction other than that being discussed. Because the discussion centers on the context of judicial practice, this phraseology does not refer to statutes, administrative regulations, or any form of non- 
something to the person citing, and presumably [the author intends them to] have some meaning to a reader." 24 That is, "citation serves the purpose of locating the immediate decision and reasoning within the context of [other] decisions." 25 In addition, references to cases and courts are quantifiable and may be analyzed empirically, affording a useful metric for the discussion at hand. For example, it is possible to determine the frequency with which a foreign court or case is cited. Furthermore, absent explicit reference in a judicial opinion, it is impossible to determine whether and to what extent foreign precedent was influential or even considered by the deciding court.

\section{A. Use of Foreign Precedent by the U.S. Supreme Court}

One element of the emerging judicial dialogue is the demonstrable influence of foreign precedent on the U.S. Supreme Court. A brief survey will suffice, because Professor Steven Calabresi and Stephanie Zimdahl have already completed a thorough study of this topic. ${ }^{26}$

As an initial matter, U.S. Supreme Court references to foreign sources of law have been far more frequent than might be commonly known. ${ }^{27}$ While the practice may have become more prevalent in the twentieth century, ${ }^{28}$ it has always been a feature of U.S. Supreme Court jurisprudence. ${ }^{29}$ In their review, Calabresi and Zimdahl identify five common situations in which the Court has cited or referred to foreign

judicial argumentation (including briefs and court documents, as well as law review articles and other academic works).

24. Peter McCormick, American Citations and the McLachlin Court: An Empirical Study, 47 Osgoode HALL L.J. 83, 87 (2009) (quoting John Henry Merryman, The Authority of Authority: What the California Supreme Court Cited in 1950, 6 STAN. L. REV. 613, 613 (1954)) [hereinafter McCormick 2].

25. Id.

26. See Stephen G. Calabresi \& Stephanie Dotson Zimdahl, The Supreme Court and Foreign Sources of Law: Two Hundred Years of Practice and the Juvenile Death Penalty Decision, 47 WM. \& MARY L. REV. 743 (2005) (reviewing and analyzing references to foreign precedent by the U.S. Supreme Court over the lifetime of the Court). Unfortunately, Calabresi and Zimdahl do not provide an empirical tally of the cases citing foreign law. Rather, their work focuses on an examination only of "striking" cases in which the Supreme Court has referred to foreign law. Id. at 754. In pursuit of a more complete picture of the influence of foreign precedent on the U.S. Supreme Court, it would likely prove useful to have quantitative data regarding citation to foreign authority, including a breakdown by Justice.

27. Id. at 907 (concluding, after a lengthy review of over 200 years of Supreme Court practice, that the Court's reference to foreign law is rather commonplace).

28. Id. (arguing that "the pace of the Court's reliance on foreign sources of law has picked up in the last sixty-five years ....").

29. Id. at 838-39 (noting that research demonstrates a steady escalation of references to foreign precedent over the history of the Court). 
law: 1) cases involving determinations of reasonableness; 2) cases where the Court has sought guidance in interpreting ambiguous language; 3) criminal cases, which account for many of the Court's references to foreign precedent generally; 4) cases where the Court has sought to provide logical reinforcement of its decisions; and 5) cases where the Court needs empirical support for arguments about possible consequences of proposed legal reforms-i.e. to demonstrate the potential impact of legal rules by noting how they have played out in other jurisdictions. ${ }^{30}$ Calabresi and Zimdahl note two categories of cases in which the Supreme Court has rarely referred to foreign precedent, namely cases hinging on interpretations of the original meaning of the Constitution and cases rooted in the distinctive structure of the U.S. government and its particular form of federalism. ${ }^{31}$

This history notwithstanding, contemporary reference to foreign precedent by the U.S. Supreme Court is controversial, particularly in the adjudication of constitutional issues, and has been debated at length in scholarly literature. ${ }^{32}$ While the academic discussions are insightful,

30. Id. at 884 .

31. Id. at 885 .

32. For arguments against citing foreign precedent, see, for example, Roger P. Alford, Misusing International Sources to Interpret the Constitution, 98 AM. J. INT'L L. 57 (2004) (arguing that the use of foreign precedents generally is inadvisable, and outlining some potential misuses that might occur in the citation of foreign precedents); Roger P. Alford, Four Mistakes in the Debate on Outsourcing Authority, 69 ALB. L. REV. 653 (2006) ("It is a grievous error to share Justice Blackmun's longing for a 'day when the majority of the Supreme Court will inform almost all of its decisions almost all of the time with a decent respect to the opinions of mankind." (quoting Harry A. Blackmun, The Supreme Court and the Law of Nations, 104 YALE L.J. 39, 49 (1994))); John O. McGinnis, Foreign to Our Constitution, $100 \mathrm{NW}$. U. L. REV. 303 (2006) (arguing that, even on a justice-oriented justification, the use of foreign precedent should not be used as authority in American constitutional law); Richard Posner, No Thanks, We Already Have Our Own Laws, LEGAL AFF., July|August 2004, http://www.legalaffairs.org/issues/July-August-2004/feature posner_julaug04.msp (identifying four distinct problems with the use of foreign precedent as authority, and asserting that the problem is not learning from abroad, but treating foreign precedent as authority "as if the world were a single legal community."); John Yoo, Peeking Abroad?: The Supreme Court's Use of Foreign Precedents in Constitutional Cases, 26 U. HAW. L. REV 385 (2004) (arguing that, if used for more than mere "ornamentation" of opinions, citation to foreign precedent raises separation of powers concerns and conflicts with the rationale underlying U.S. judicial review as articulated in Marbury v. Madison). For arguments in favor of citing foreign precedent, see, for example, Amann, supra note 14, 1319 (arguing that the U.S. Supreme Court should provide guidance for when comparative review of foreign materials is acceptable, and a framework for such consultation); Choudhry, supra note 8 (arguing that the globalization of constitutionalism requires that theories of constitutional interpretation come to terms with it, and analyzing three distinct, comparative constitutional methodologies: universalist interpretation, genealogical interpretation, dialogical interpretation); Vicki Jackson, Yes Please, I'd Love to Talk With You, LEGAL AFF., July|August 2004, http://www.legalaffairs.org/issues/July- 
more interesting for present purposes is the debate among the people who actually choose whether and when to cite foreign law. ${ }^{33}$ The Justices of the U.S. Supreme Court have debated the merits of comparative analysis in their published opinions, ${ }^{34}$ speeches, and public appearances. ${ }^{35}$ Justices of other courts have also weighed in on the subject. ${ }^{36}$

\section{Contours of the Debate}

In early 2005, U.S. Supreme Court Justices Stephen Breyer and Antonin Scalia engaged in a public dialogue, held at the Washington College of Law, American University, and billed as "A Conversation on the Relevance of Foreign Law for American Constitutional Adjudication." 37 In the course of their discussion, Justices Breyer and

August-2004/feature_jackson_julaug04.msp (arguing that the Court has a long history of reference to foreign legal sources, and that justices should not ignore foreign legal material if it can help the Court reach a better understanding of U.S. law); Austen L. Parrish, Storm in a Teacup: The U.S. Supreme Court's Use of Foreign Law, 2007 U. ILL. L. REV. 637, 638-42 (2007) (criticizing arguments against the citation of foreign precedents as misplaced, and arguing that the use of foreign legal material is sensible, and compatible with American constitutionalism and the proper role of the judiciary); Mark C. Rahdert, Comparative Constitutional Advocacy, 56 AM. U. L. REv. 553, 560-61 (2007) (arguing that comparative constitutional analysis is valuable, and concluding that its benefits outweigh any challenges); Lefler, supra note 4, at 166-67 (contending that by rejecting comparative constitutional analysis, the United States loses out on the wisdom transnational judicial dialogue advances, and the opportunity to contribute and influence this dialogue); Moon, supra note 15, 246-47 (concluding that the U.S. Supreme Court, as a leader of a world legal community, should engage in limited comparative constitutional "dialogue" in order to help other constitutional courts draw the line between acceptable use of comparative materials and dangerous reliance on comparative constitutional analysis).

33. A secondary reason for preferring the arguments of practitioners to a review of the academic debate is that many of the same themes in the latter are more accessibly articulated in the former.

34. See, e.g., Roper v. Simmons, 543 U.S. 551, 575-79, 604-05, 622-28 (2005); Lawrence v. Texas, 539 U.S. 558, 572-73, 598 (2003); Atkins v. Virginia, 536 U.S. 304, 316 \& n.21, $322(2002)$.

35. See, e.g., The Relevance of Foreign Legal Materials in U.S. Constitutional Cases: A Conversation Between Justice Antonin Scalia and Justice Stephen Breyer, 3 INT'L J. CoNST. L. 519 (2005) (containing the transcript of a debate between Justices Scalia and Breyer held January 13, 2005, at the American University Washington College of Law in Washington, D.C.) [hereinafter Conversation Between Scalia \& Breyer].

36. See Liptak, supra note 1 (quoting Israeli Supreme Court Justice Aharon Barak and Australian High Court Justice Michael Kirby).

37. 2005 Founders' Celebration Events, AM. UNIV. ColL. OF LAW, http://www.wcl.american.edu/secle/founders/2005/050113.cfm (last visited Nov. 12, 2010); see also Conversation Between Scalia \& Breyer, supra note 35. 
Scalia agree that there are certain instances where citing to foreign law in Supreme Court opinions is appropriate, but on the whole, Justice Breyer is supportive and Justice Scalia is critical of the practice.

Justice Breyer generally supports citing to foreign precedent in opinions, though he is careful to note that foreign precedent in no way binds American courts. ${ }^{38}$ In his remarks, Justice Breyer outlines three rationales in support of the limited comparative practice he proposes. First, he argues that citing foreign precedent could bolster fledgling democratic institutions by lending the Court's prestige to their efforts. ${ }^{39}$ Second, he suggests that some issues are better understood as "lawrelated human question[s]," as opposed to technically legal questions. Such "law-related human questions" merit reference to the ways other human beings (i.e. foreign judges) have addressed them. ${ }^{40}$ Third, Justice Breyer argues that reference to foreign precedent can help inform the judicial process by illustrating the possible implications or consequences of a particular decision. ${ }^{41}$

Michael Kirby, former Justice of the High Court of Australia, has made similar arguments. He suggests that,

[t]o many judges in national courts, faced with cases for decision involving the meaning of their own constitutional charters of rights, it has often seemed appropriate and useful, over recent years, to reach for the exposition of analogous problems, written by judges and decisionmakers in the courts of other countries . . grappling with similar problems. ${ }^{42}$

38. Conversation Between Scalia \& Breyer, supra note 35, at 523.

39. See id. ("In some foreign countries, people are struggling to establish institutions that will help them protect democracy and human rights .... They want to demonstrate the importance of having independent judges enforce constitutionally protected human rights .... And if we sometimes refer to their decisions, the references may help those struggling institutions.").

40. See id. at $\mathbf{5 2 8}$ (giving Breyer's statement that "American and foreign judges alike are human beings using similar legal texts, dealing with a somewhat similar human problem"; thus justifying "reaching out to those other nations, reading their decisions ... even though they cannot determine the outcome of a question that arises under the American Constitution.").

41. See id. at 537 ("If, for example, a foreign court, in a particular decision, had shown that a particular interpretation of similar language in a similar document had had an adverse affect on free expression, to read that decision might help me apply the American Constitution.").

42. Michael Kirby, Citation of Foreign Decisions in Constitutional Adjudication: The Relevance of the Democratic Deficit, 43 SUFFOLK L. REV.117, 117 (2009). 
In doing so, Justice Kirby notes that foreign judges are not showing improper deference, loyalty, or obedience to the rulings of foreign courts. ${ }^{43}$ Rather, foreign precedent concerning related or analogous problems arising under domestic law is seen as "helpful and informative and therefore useful in the development of the municipal decisionmaker's own opinions." 44 Addressing critics of the practice, Justice Kirby argues that reference to foreign precedent merely "helps the municipal decision-maker to see his or her problem in a wider context," a function similar to that Justice Breyer ascribes to citations of law review articles and treatises. ${ }^{45}$

Justices Breyer and Scalia agree that citing foreign precedent might be justified to show that the Court's adoption of a given rule would not lead to disastrous results. ${ }^{46}$ This minor point of agreement notwithstanding, Justice Scalia is critical of the practice of citing foreign law. First, he argues that citation to foreign precedent lends itself to manipulation. That is, with a world of jurisprudence from which to draw, a judge can almost always find some precedent supporting his or her desired outcome-a kind of judicial cherry picking. ${ }^{47}$ Second, he contends that American judges do not understand the context in which foreign decisions were rendered, leading to inappropriate comparisons. ${ }^{48}$ Finally, Justice Scalia argues that foreign law is irrelevant, since the Constitution was not meant to grow or change, but to remain a static baseline against which legislative acts are measured. ${ }^{49}$

43. $I d$.

44. Id.

45. Id. at 130; Conversation Between Scalia \& Breyer, supra note 35, at 541.

46. See Conversation Between Scalia \& Breyer, supra note 35, at 526 (quoting Justice Scalia: "Of course, you can cite foreign law to show-Justice Breyer gave an example-to show that if the Court adopts this particular view of the Constitution, the sky will not fall.").

47. See id. at 531. Chief Justice John Roberts, during his confirmation hearings, espoused a similar concern. In responding to a question from Senator Jon Kyl (R-AZ), Roberts stated that with "[f]oreign law, you can find anything you want. . . . And that actually expands the discretion of the judge. It allows the judge to incorporate his or her own personal preferences .... I think that's a misuse of precedent." Confirmation Hearing on the Nomination of John G. Roberts, Jr. to be Chief Justice of the United States: Hearing Before the S. Comm. on the Judiciary, 109th Cong. 616-17 (2005), available at http://frwebgate1.access.gpo.gov/cgi-bin/TEXTgate.cgi?WAISdocD=HUFCQ0/0/1/0\&WAIS action=retrieve.

48. Conversation Between Scalia \& Breyer, supra note 35, at 528-29 ("One of the difficulties using foreign law is that you don't understand what the surrounding jurisprudence is.").

49. Id. at 535 " "I regard the Constitution as having set a floor to what American society can democratically do. [If that floor says nothing about issue $\mathrm{X}$, it is] not the job of the Constitution to change things by judicial decree; change is brought about by democratic legislation."). 
John Greaney, former Justice of the Massachusetts Supreme Judicial Court, is similarly wary of citing to foreign precedent. First, even contextual reference to foreign law disregards what Justice Greaney terms the "uniqueness principle": the idea that no matter how similar another country's law might be, each state has a cultural and social milieu that shapes and defines its laws. ${ }^{50}$ In addition, differences in the purposes and processes of judicial selection have an impact on what he terms the "art and science of judging."51 The resulting differences therefore render practices and decisions of foreign courts inapposite. ${ }^{52}$ Finally, Justice Greaney echoes Justice Scalia's worry about jurisprudential cherry picking-what Justice Greaney describes as jurisprudential "opportunism that is incongruent with American constitutional adjudication." 53

Considering the role cast for foreign precedent by its proponents and the trepidation of its opponents, one may tentatively conclude that the influence of foreign jurisprudence on the U.S. Supreme Court is limited to a modest background role. Based on the descriptions offered by Justice Breyer and Justice Kirby as to the use of foreign precedent, the influence of foreign precedent is perhaps less than the volume ${ }^{54}$ of the debate might indicate. Certainly some shared ideas are influential, but this influence seems limited to providing background information, rather than serving a dispositive role in a given case.

Lastly, it may be tempting to infer from the preceding discussion that the hostility of some prominent U.S. judges to the use of foreign precedent may leave foreign jurists less inclined to cite U.S. precedent. However, that conclusion is premature, and to accurately assess the extent of the U.S. Supreme Court's influence abroad, it is necessary to examine the use of U.S. precedent overseas.

50. John M. Greany, An Argument Against Citation of Foreign Decisions in Constitutional Adjudication, Panel Remarks at the Suffolk University Twenty Ninth Annual Donahue Lecture Series, in Citation to Foreign Decisions in Constitutional Adjudication, 43 SUFFOLK U. L. REV. 135, 145 (2009).

51. Id. at 146 .

52. See id. at $145-46$.

53. Id:; see also Cheryl Saunders, The Use and Misuse of Comparative Constitutional Law, 13 IND. J. GLOBAL LEGAL STUD. 37, 67 (2006) (mentioning that while selective manipulation of citation from a home jurisdiction is also possible, the practice "can be more readily detected").

54. "Volume" refers to both the vitriol of some critiques, and the sheer amount of material addressing the subject. 


\section{B. Use of U.S. Supreme Court Precedent Abroad}

In contrast to the vigorous debate that characterizes the U.S. Supreme Court's use of foreign case law, many courts in other countries take a more expansive view of the use of foreign precedent. For example, in Australia, ${ }^{55}$ Canada, ${ }^{56}$ India, ${ }^{57}$ Israel, ${ }^{58}$ New Zealand, ${ }^{59}$ Singapore, ${ }^{60}$ and South Africa, ${ }^{61}$ to name but a few, reference to U.S. precedent is not uncommon. ${ }^{62}$ Many of the judges in these countries offer justifications for their comparative endeavors similar to those advanced by Justices Breyer and Kirby. ${ }^{63}$

In Canada, citation to U.S. precedent is seen as "an aspect of a more general trend" of comparative exercise. ${ }^{64}$ Indeed, the entire practice of referring to foreign precedent is merely reflective of the "legal cosmopolitanism" that Canadian jurists have found to be "a valuable source of enrichment and greater sophistication."65 In Canada comparative practice has been used to provide important background on

55. E.g., Paul E. von Nessen, The Use of American Precedents by the High Court of Australia, 1901-1987, 14 ADEL. L. REV. 181, 184-86 (1992) [hereinafter von Nessen, American Precedents].

56. E.g., McCormick 2, supra note 24, 108-113.

57. E.g., Anthony Lester, The Overseas Trade in the American Bill of Rights, 88 COLUM. L. REv. 537, 545-47 (1988).

58. E.g., Pnina Lahav, American Influence on Israel's Jurisprudence of Free Speech, 9 HASTINGS CONST. L.Q. 21, 23-27 (1981).

59. E.g., James Allan et al., The Citation of Overseas Authority in Rights Litigation in New Zealand: How Much Bark? How Much Bite?, 11 OTAGo L. REv. 1, 2, 5-6 (2007).

60. E.g., Lester, supra note 57, at 541-44.

61. See, e.g., Shannon Ishiyama Smithey, A Tool, Not a Master: The Use of Foreign Case Law in Canada and South Africa, 34 COMP. POL. STUD. 1188, 1207-09 (2001).

62. Indeed, U.S. constitutionalism more generally has left an undeniable imprint on the constitutional traditions of, among others, Germany, Japan, and Korea. See generally Helmut Steinberger, American Constitutionalism and German Constitutional Development, in Constitutionalism AND RIGHTS: THE INFLUENCE OF THE U.S. CONSTITUTION ABROAD (Louis Henkin and Albert Rosenthal, eds. Columbia Univesity Press: 1990) at 199 (discussing the history of U.S. constitutional influence on Germany); and Lawrence W. Beer, Constitutionalism and Rights in Japan and Korea, in CONSTITUTIONALISM AND Rights: The INFluence of THE U.S. Constitu'tion ABROAD (Louis Henkin and Albert Rosenthal, eds. Columbia University Press: 1990) at 225 (discussing the history of U.S. constitutional influence on Japan and Korea).

63. E.g., Bijon Roy, An Empirical Survey of Foreign Jurisprudence and International Instruments in Charter Litigation., 62 U. TORONTO FAC. L. REV. 99, 109 (2004) (quoting Israeli Supreme Court President, Aharon Barak, "The purpose of [ comparison is inspiration. . . Comparative law is a 'guide to finding the appropriate solution ... [that] grants comfort to the judge and gives him the feeling that he is treading on safe ground.").

64. Gerard V. La Forest, The Use of American Precedents in Canadian Courts, 46 ME.

L. REV 211,216 (1994).

65. Id. at 217 . 
legal questions via consideration of "the successes and failures of various approaches" taken by other states and is driven by a desire "to benefit from expertise acquired [by longstanding non-Canadian constitutional jurisprudence]."66

Justices from Australia have advanced similar arguments. For example, Justice Kirby has been an outspoken advocate of comparative reference to foreign precedent. ${ }^{67}$ As he notes in a recent article, references to foreign precedent by the High Court of Australia are quite uncontroversial. Such references are used because they "have been found helpful and informative and therefore useful in the development of the municipal decision-maker's own opinions concerning apparently similar problems presented by the municipal constitution or other laws."68 And while reference to international law in certain contexts may be controversial, ${ }^{69}$ the utility of referring to jurisprudence of other countries as a means of elucidating the meaning of the Australian Constitution remains unquestioned. ${ }^{70}$

Although courts in many countries commonly refer to foreign precedent, Canada and Australia are particularly useful for measuring the influence of the U.S. Supreme Court abroad. Of obvious benefit is the fact that these countries speak English, ${ }^{71}$ but of even more benefit is the fact that observers have extensively studied and documented the practices of the Supreme Court of Canada and the High Court of Australia with special attention to the citation of U.S. precedent. Section B will end by noting any conclusions that can be drawn from the discussion, with an eye to addressing arguments that the influence of the U.S. Supreme Court is waning due to hostility toward comparative practice. $^{72}$

\section{Canadian Reference to U.S. Precedent and to the U.S. Supreme Court}

Anecdotal evidence suggests that, largely as a result of the country's history, Canadian courts have long cited foreign precedent ${ }^{73}$ in general

66. L'Heureux-Dubé, supra note 13 , at 19-20. Note the similarity between this justification and that provided by Justice Breyer during his public conversation with Justice Scalia. See Conversation Between Scalia \& Breyer, supra note 35, at 523.

67. See, e.g., supra Part I.A.1.

68. Kirby, supra note 42 , at 117.

69. Id. at 123 (quoting Al-Kateb v. Godwin (2004) 219 C.L.R. 562 at 589-95 (McHugh, J. concurring)).

70. Id. at 124 .

71. This is a distinct advantage given the author's monolingual training.

72. See, e.g., Lefler, supra note 4, at 167; Liptak, supra note 1.

73. Here foreign precedent refers to published, non-Canadian judicial decisions. 
and U.S. precedent in particular. ${ }^{74}$ Reference to U.S. precedent in the twentieth century began increasing with the end of appeals to the United Kingdom in 1949.75 The practice has been most pronounced in areas of constitutionalism and human rights. 76 Reference to U.S. jurisprudence increased with the adoption of the Canadian Charter of Rights and Freedoms in 1982,77 though such references "would always have to be adjusted to suit the different Canadian context."78 Other anecdotal evidence reinforces this picture of Canadian constitutional jurists seeking to benefit from U.S. experience, particularly the experience of the Warren and Burger Courts. ${ }^{79}$ However, painting a more verifiable picture of the Supreme Court of Canada's (SCC) use of U.S. precedent-the U.S. Supreme Court in particular-requires turning to empirical study.

Two particularly relevant studies 80 focus on the citation of U.S. precedent by the SCC. One study by S.I. Bushnell reviews citations from the SCC's inception in 1876 until $1983 .{ }^{81}$ The other study, conducted by Peter McCormick, was completed in two parts. Part one ${ }^{82}$ analyzes citations from 1945 to 1994 (McCormick 1), and part two ${ }^{83}$ analyzes citations from 2000 to 2008 (McCormick 2). Bushnell and McCormick use slightly different methodologies in their studies. Bushnell counts cases citing to U.S. authority, whereas McCormick counts citations themselves. ${ }^{84}$ The pertinent differences are noted in the review below.

\section{a. By the Numbers}

As an introductory remark, and to provide some context for the following discussion, it merits observing that the Supreme Court of

74. La Forest, supra note 64, at 212-13.

75. In 1949, the Judicial Committee of the Privy Council in London ceased to be the court of final appeal. L'Heureux-Dubé, supra note 13, at 17.

76. Id. at 18 .

77. Canadian Charter of Rights and Freedoms, Part I of the Constitution Act, 1982, being Schedule B to the Canada Act, 1982, c. 11 (U.K.).

78. La Forest, supra note 64, at 214.

79. See, e.g., L'Heureux-Dubé, supra note 13, at 19-21.

80. Here, relevant studies are those that focused specifically on U.S. citations or noted the frequency of U.S. Supreme Court precedents as a sub-category of U.S. authority more generally.

81. S.I. Bushnell, Note, The Use of American Cases, 35 U. N.B. L.J. 157 (1986).

82. Peter McCormick, The Supreme Court of Canada and American Citations 1945 1994: A Statistical Overview, 8 SUPREME CT. L. REV. 527 (1997) [hereinafter McCormick 1].

83. McCormick 2, supra note 24.

84. To be clear, Bushnell counts cases citing U.S. authority, whereas McCormick's studies count individual citations. 
Canada cites itself more often than any other source of authority. ${ }^{85}$ Canadian appellate courts are cited about one-third as often as SCC precedent, and Canadian trial courts are cited half as often as Canadian appellate courts, or one-sixth as often as SCC precedent. ${ }^{86}$ U.K. precedents are cited one-twelfth as often as SCC authority; U.S. precedents are cited half as often as U.K. authority, or one-twentyfourth as often as SCC authority; and other authorities are cited oneforty-eighth as often as SCC precedent. ${ }^{87}$ The total number of judicial citations counted in the combined McCormick studies is 53,602.88

According to McCormick, between 1945 and 2008, approximately half of all citations to U.S. authority were references to decisions of the U.S. Supreme Court. ${ }^{89}$ The overall number of citations to U.S. authority remained fairly consistent between the two time periods covered by McCormick's studies-3.5\% of all SCC citations between 2000 and $2008^{90}$ and $4.3 \%$ of all SCC citations between 1945 and 1994.91 By contrast, if one uses the Bushnell method to count the number of cases

85. McCormick 2, supra note 24 at 91.

86. Id. (referring to tbl. 1).

87. Id.

88. McCormick 1 analyzes over 40,000 citations, and McCormick 2 analyzes 13,602. McCormick 1, supra note 82, at 532; and McCormick 2, supra note 24 at 91 . To illustrate these numbers, consider Table 1 from id. at 91 :

Table 1: Sources of Judicial Authority-SCC, 2000-2008

\begin{tabular}{|l|l|l|}
\hline Source of Citations & Number & Percentage \\
\hline SCC & 7,989 & $58.7 \%$ \\
\hline Canadian Appeal Courts & 2,452 & $18.0 \%$ \\
\hline Canadian Trial Courts & 1,479 & $10.9 \%$ \\
\hline England & 824 & $6.1 \%$ \\
\hline United States & 476 & $3.5 \%$ \\
\hline Other Countries \& Supranational & 220 & $1.6 \%$ \\
\hline Canadian Boards \& Tribunals & 162 & $1.2 \%$ \\
\hline Total & 13,602 & \\
\hline
\end{tabular}

89. McCormick 2, supra note 24, at $91-93$ (identifying this ratio for the period 20002008, and commenting that the number is consistent with his prior study covering 1945 1994). See also id. at 92 (referring to Table 3 (below) for the 2000-2008 breakdown); McCormick 1, supra note 82, at 541 .

Table 3: SCC Citations to American Judicial Authority 2000-2008

\begin{tabular}{|l|l|l|l|}
\hline Source of Citations & Number & Median Date & Percentage \\
\hline US Supreme Court & 220 & 1973 & $46.2 \%$ \\
\hline US Federal Courts & 110 & 1989 & $23.1 \%$ \\
\hline US State Courts & 140 & 1984 & $29.4 \%$ \\
\hline US Board \& Tribunal & 6 & 1990 & $1.3 \%$ \\
\hline Total & 476 & 1981 & \\
\hline
\end{tabular}

90. McCormick 2, supra note 24, at 91 tbl.1.

91. See McCormick 1, supra note 82, at 532. 
that cite to some U.S. decision during the pre-Charter period (18761983), U.S. authority accounted for roughly $9 \%$ of all SCC citations. ${ }^{92}$ Analyzing McCormick 2's data (2000-2008) using the same method, one finds that $14 \%$ of the total cases reference the U.S. Supreme Court, a large subsection of the $20 \%$ of total cases that reference any U.S. authority. ${ }^{93}$

McCormick 1 provides ratios of the SCC's citation to its own precedent relative to citation to U.S. Supreme Court decisions by casetype. ${ }^{94}$ Overall, the SCC cited itself eight times for every one cite to the U.S. Supreme Court; the same ratio appeared in those cases identified as Charter cases. ${ }^{95}$ The ratio for public law and criminal law cases stands at ten SCC citations for every one U.S. Supreme Court citation,,$^{96}$ and in private law cases the ratio stands below four SCC citations for every one U.S. Supreme Court citation. ${ }^{97}$

It is interesting to note that for the period of the McCormick 1 study, private law cases constituted a growing segment of the SCC docket. U.S. state court decisions accounted for three-fifths of the citations to U.S. authority in private law cases. ${ }^{98}$ Just under half of all citations to the U.S. Supreme Court appear in Charter cases, but, in Charter cases, citations to the U.S. Supreme Court represent $75 \%$ of the total number of citations to U.S. authority. ${ }^{99}$

\section{b. Trends}

During the pre-Charter era, Bushnell observed that the SCC cited significantly more U.S. authority prior to the early 1900 s, with a resurgence from 1970 to 1983 , the last decade of the study. ${ }^{100}$ The period exhibiting the greatest number of citations to U.S. precedent was from 1876 to 1886 , during which time $19 \%$ of SCC decisions included some reference to U.S. authority. ${ }^{101}$ Bushnell suggested that because the SCC

92. Bushnell, supra note 81 , at 160 .

93. McCormick 2, supra note 24, at 93-94 tbl.4.

94. McCormick 1, supra note 82 , at 540 tbl.5. These numbers represent the 10-year period between 1983 and 1993.

95. Id. "Charter cases" refers to cases arising under the Canadian Charter of Rights and Freedoms, discussed supra note 77.

96. Id.

97. Id.

98. Id. at 542 .

99. Id. at 542 .

100. See Bushnell, supra note 81, at 160-61 tbl.2.

101. Id. 
was new, it looked abroad more frequently to find precedent with which to adjudicate. ${ }^{102}$

Citation to U.S. authority increased from 1945 to 1994 (beginning at $1.5 \%$ of all citations, and ending at $6.87 \%),{ }^{103}$ with a spike in $1990 .{ }^{104} \mathrm{It}$ is noteworthy that during this same period, the SCC cited all authority more frequently, hence "American references represent[ed] a growing share of a growing pie."105 However, between 2000 and 2008, "American authority [was] not a major feature of the case law of the McLachlin Court, and [was] somewhat less prominent than was the case for the two preceding Chief Justiceships." 106 The decrease after the 1990s could be attributed to the significant turnover on the SCC between 1994 and 2000-only Chief Justice McLachlin was on the SCC in both 1994 and 2000.107

A final trend identified by the studies shows that the median "age" of U.S. Supreme Court cases cited by the SCC is thirty years. ${ }^{108}$ Both McCormick 1 and McCormick 2 found the Warren and Burger Courts to be the most commonly cited by the SCC. 109 The consistent preference for the Warren and Burger Courts' opinions over more recent U.S. Supreme Court decisions weakens Ginsburg's claim that the decline in citation to U.S. authority is due to political disagreement with the George W. Bush Administration. ${ }^{110}$

102. See id. at 163-64. Bushnell also suggests that a possible reason for the increased frequency of U.S. citations during this early period lies in the underlying philosophy of law at the time. During the nineteenth century and into the very early twentieth century it was still commonplace to speak of the common law as related to natural law, merely awaiting discovery. Thus, it would not matter if the law had been discovered by an American, Canadian, or English court. See id.

103. McCormick 1, supra note 82, at 533 tbl.1.

104. Id. at 534 fig. 1 .

105. Id. at 534 .

106. McCormick 2, supra note 24 , at 94 .

107. See id. at 95-96. McCormick also notes that "what the figures from the 1990s suggest, and those from the new decade do not, is a frequency of citation implying a steady conversation about American judicial ideas. This conversation was joined on a regular basis by most of the members of the Court; there were half-a-dozen members of that Court who cited American decisions more than a dozen times every year." Id. at $\mathbf{9 5 .}$

108. Id. at 93. This contrasts with SCC citation to its own precedent at a much "younger" interval, with a median age of six years. See McCormick 2, supra note 24, at 101-02.

109. See id. at 98-99 tbl.6; McCormick 1, supra note 82, at 546.

110. Supra note 12, and accompanying text. The SCC preference for older USSC precedent provides some support for an inference that, beginning in the $1980 \mathrm{~s}$, the U.S. Supreme Court began moving in a different direction than other national courts. 


\section{c. Other Explanations and Conclusions}

Although some of the preceding discussion considers citation to U.S. precedent in general, the SCC has always cited to the U.S. Supreme Court more than any other U.S. court.111 While citation to the IU.S. Supreme Court only rose far above citation to other U.S. courts during the Charter era, the overall percentages remained fairly consistent over both McCormick's studies. From 1945 to 1994, the percentage breakdown of citation to the U.S. Supreme Court, other federal courts, and state courts was approximately $50 \%, 24 \%$, and $26 \%$, respectively. ${ }^{112}$ From 2000 to 2008 , the percentage breakdown was roughly $47 \%, 23 \%$, and $30 \%$, respectively. ${ }^{113}$ This data allows one to draw conclusions, discussed below, about the influence of the Supreme Court by inference, even when the data speaks only of citations to U.S. authority in general.

Legal education is one commonly suggested reason for the general increase in citation to U.S. authority over the time periods studied. Proponents argue that Canadian judges and lawyers who receive at least some of their training in the United States are more inclined to both cite and base arguments on U.S. authority. ${ }^{114}$ Similarly, Gerard La Forest, a former Justice of the Supreme Court of Canada, posited the U.S. legal education of Canadian legal scholars as one possible reason why Canadian jurists commonly cite U.S. authority. ${ }^{115}$ Others have commented that the availability and use of American law reporters in Canadian law schools may also contribute to a willingness to cite U.S. authority. ${ }^{116}$

111. McCormick 1, supra note 82, at $541 \mathrm{n} .31$.

112. McCormick 1 shows that the percentage breakdown of USSC, other federal courts, and state courts from 1945 to 1983 is 40/20/40, while the breakdown in 1997 was 50/20/25. The numbers provided above are derived from calculations performed on the data provided in $i d$. at 541, n.31.

113. McCormick 2, supra note 24, at 92-93 tbl.4.

114. See Bushnell, supra note 81, at 169. A similar view is expressed by former SCC Justice Claire L'Heureux-Dubé. L'Heureux-Dubé, supra note 13, at 20-21 ("When time comes to look for solutions to similar problems, [lawyers and judges who received legal training abroad] naturally turn for inspiration and comparison to those jurisdictions whose ideas are familiar to them.").

115. La Forest, supra note 64, at 212-13.

116. See, e.g., J.M. MacIntyre, The Use of American Cases in Canadian Courts, 2 U. BRIT. CoLUM. L. REv. 478, 478 (1966). The advent of electronic databases, such as Westlaw and LexisNexis in the United States, and the World Legal Information Institute, and the practice of some courts posting published decisions online have made far more international law and foreign law available to courts around the globe. As a result, it is unclear whether the availability of foreign precedent during law school is determinative of a lawyer's subsequent willingness to cite foreign law. Examples of courts posting decisions online include the U.S. Supreme Court, European Court of Human Rights, Inter-American 
Yet of the sixty-two Justices to sit on the SCC during the period Bushnell studied, six were educated in the United States-five at Harvard, and one at the University of Michigan. ${ }^{117}$ Moreover, according to McCormick 1, the education explanation is not supported by the data. McCormick notes that only four of the top eighteen SCC Justices (ranked by their frequency of citation to U.S. authority) and only one of the top six received any training in the United States. ${ }^{118}$ These U.S.trained SCC Justices ${ }^{119}$ account for only one-sixth of the "judge years" accounted for in the McCormick 1 study, and only $32.4 \%$ of U.S. citations overall. ${ }^{120} \mathrm{McC}$ Cormick 2 echoes this finding and suggests that the practice of citing U.S. authority began with justices familiar with U.S. authority from their legal training and spread to other justices. ${ }^{121}$ When McCormick 2 was published, "for almost the first time since the Second World War, there [was] not a single judge on the SCC with a law degree from an American University."122

What, then, can be said about the overall influence of U.S. precedent on Canadian jurisprudence? It seems clear that "[d]espite geographical proximity, considerable cross-border movement, similar economies and extensive commercial linkages, U.S. courts have had little direct effect on the evolution of Canadian jurisprudence." 123 Yet even absent a direct

Court of Human Rights, International Court of Justice, and the European Court of Justice, to name but a few.

117. Bushnell, supra note 81, at 169. During the editing process, I was asked to account for the potential impact of judicial clerks who may have received their legal education in the United States. The subject of clerks is arguably irrelevant to the discussion presented here for two reasons. First, anecdotal evidence suggests that the role of judicial clerks in the drafting of opinions is that of a ghostwriter, not a principal author. A clerk's role is to prepare a draft as though the judge had written it. Secondly, and most importantly, the final published opinion will include only those citations the judge has determined are appropriate. It is ultimately the judge's opinion, without so much as a footnote identifying the clerk who prepared the first draft. The idea that relatively inexperienced law clerks have so much influence that they shape their judge's citation practices is dubious at best. It is hard to imagine Justice Scalia, for example, authoring an opinion citing foreign law in a manner similar to Justice Kirby simply because an enterprising law clerk thought to include the citations in a rough draft. I recognize that this discussion assumes the process of judicial opinion drafting in other countries is similar to that common in the United States. This assumption may be unwarranted, but is a topic well beyond the scope of this essay.

118. McCormick 1, supra note 82, at 537. One of the top six, interestingly, is Gerard La Forest.

119. Id. For the complete list of the SCC's U.S. citations per year, see id. at 546 tbl.2.

120. Id. at 537. "Judge years" refers to the number of years of experience in the aggregate of the judges on the court. For example, a five judge panel in which each sitting judge had served for six years would add up to a total of thirty "judge years."

121. McCormick 2, supra note 24, at 97.

122. Id.

123. McCormick 1, supra note 82 , at 533. 
effect, the upward trend of SCC citation to U.S. authority during most of the twentieth century cautions against reading too much into the more recent, modest decline. Correlations do not prove causation, and perhaps the dip in U.S. citations in the early twenty-first century is better explained by a maturing SCC jurisprudence, rather than an effect caused by U.S. hostility to comparative exercise, or political disagreements. Thus, there is reason to be skeptical of claims that any diminishing influence is correctable through increased U.S. participation in the emerging transnational judicial dialogue, at least vis-à-vis Canada.

\section{Australian Reference to U.S. Precedent}

Like Canada, Australia has a long history of citing foreign precedent in general, and U.S. precedent in particular. Both countries share a history as part of the British Commonwealth of Nations, ${ }^{124}$ and like Canada, Australian citation to U.S. precedent began roughly the same time as the last bonds of colonialism were loosening. ${ }^{125}$ Additionally, there exists abundant anecdotal evidence describing the High Court of Australia's (HCA) citation to U.S. and other foreign precedent. ${ }^{126}$ There are also quantitative studies of the frequency with which U.S. authority is cited by the HCA.

In addition to brief discussions in larger works, 127 Paul von Nessen has tallied and analyzed HCA citation to U.S. authority over the last century, reviewing the practice from 1901 to 2002 in two separate papers. ${ }^{128}$ In his reviews, von Nessen used two slightly different

124. See von Nessen, American Precedents, supra note 55, at 181-186.

125. See id. at 184. For example, the von Nessen study discussed in this section begins with the year 1901-one year after the passage of the Parliamentary Act that constitutes Australia's Constitution. Commonwealth of Australia Act, 1900 (Imp), 63 \& 64 Victoria, c. $12, \S 9$ (U.K.) (enacting the Australian Constitution).

126. See, e.g., Bruce Topperwien, Foreign Precedents, in ThE OxForD Companion to THE High COURT OF AUSTRALIA 280, 280-81 (Tony Blackshield et al. eds., 2002) ("The High Court regularly cites cases from England, the USA, Canada and NZ, and occasionally from other common law countries. The Court rarely cites cases from non-common law countries." (emphasis omitted)); Kirby, supra note 42 (discussing how, for judges grappling with a constitutional issue, foreign or international judicial decisions dealing with a comparable issue are of a "helpful and informative" nature); Lefler, supra note 4, at 178 . 82.

127. E.g., Russell Smyth, Citations by Court, in The Oxford ComPanion to the High COURT OF AUSTRALIA, supra note 126, at 98; Topperwien, supra note 126.

128. The first paper covers the period 1901-1990. See von Nessen, American Precedents, supra note 55. The second paper summarizes the findings of the first, and proceeds to update it with new data covering the period 1991-2002. See Paul von Nessen, Is There Anything to Fear in Transnationalist Development of Law? The Australian Experience, 33 
methodologies to compile his data. In the first study (von Nessen 1), he counted individual references and citations manually from cases published in the Commonwealth Law Reports series between 1901 and 1990.129 For the second study (von Nessen 2), he took advantage of electronic databases to search for all cases reported in the Commonwealth Law Reports from 1990 to 2002 by using the names of U.S. reporter series as keywords. ${ }^{130}$ Von Nessen divided the citations tallied in these complementary studies into eight categories: constitutional law, public law, contracts and commercial law, tort law, criminal law, other common law, other statutory, and miscellaneous. ${ }^{131}$

\section{a. By the Numbers}

In absolute numbers, the High Court of Australia has typically cited its own decisions more than any other court. ${ }^{32}$ However, as a

PEPP. L. REV. 883 (2006) [hereinafter von Nessen, Australian Experience]. Because the second paper thoroughly reviews the findings of the first, the discussion in this section will generally rely on the later study for the sake of simplicity.

129. See von Nessen, American Precedents, supra note 55, at 187-93; von Nessen, Australian Experience, supra note 128, at 892-96.

130. See von Nessen, Australian Experience, supra note 128, at 914-17.

131. Id. at 895 .

132. Russell Smyth, supra note 127, at 98, 98-99 (reviewing the number of citations to authority by the High Court of Australia in five sample years -1920, 1940, 1960, 1980, 1996). The exception to this proposition, as Smyth notes, is the year 1940. Id. at 99. The data is reproduced in part below. $I d$. at 98 (omitting the more detailed breakdown by court for Australia, the United Kingdom, and "Other").

Citations by the High Court

\begin{tabular}{llllll}
\hline Cited Court & $\begin{array}{l}1920 \\
\text { No. \% }\end{array}$ & $\begin{array}{l}1940 \\
\text { No. \% }\end{array}$ & $\begin{array}{l}1960 \\
\text { No. \% }\end{array}$ & $\begin{array}{l}1980 \\
\text { No. \% }\end{array}$ & $\begin{array}{l}1996 \\
\text { No. \% }\end{array}$ \\
\hline $\begin{array}{l}\text { Total } \\
\begin{array}{l}\text { Australian } \\
\text { courts }\end{array}\end{array}$ & $524(27.8 \%)$ & $285(20 \%)$ & $1182(46.4 \%)$ & $1512(54.9 \%)$ & $5745(66.5 \%)$ \\
\hline $\begin{array}{l}\text { Total } \\
\begin{array}{l}\text { English } \\
\text { courts }\end{array}\end{array}$ & $1201(63.7 \%)$ & $942(66 \%)$ & $1041(40.8 \%)$ & $888(32.3 \%)$ & $1522(17.6 \%)$ \\
\hline $\begin{array}{l}\text { Courts in } \\
\text { other } \\
\text { countries }\end{array}$ & $89(4.7 \%)$ & $66(4.6 \%)$ & $69(2.7 \%)$ & $159(5.8 \%)$ & $470(5.4 \%)$ \\
\hline $\begin{array}{l}\text { Secondary } \\
\text { authorities }\end{array}$ & $72(3.8 \%)$ & $129(9 \%)$ & $255(10.1 \%)$ & $193(7 \%)$ & $904(10.5 \%)$ \\
\hline $\begin{array}{l}\text { Grand Total } \\
\text { (including } \\
\text { omitted } \\
\text { data) }\end{array}$ & $1886(100 \%)$ & $1428(100 \%)$ & $2547(100 \%)$ & $2752(100 \%)$ & $8641(100 \%)$ \\
\hline
\end{tabular}


percentage of total citations to authority, it appears that U.K. courts in aggregate were cited more often than even Australian courts until $1960 .{ }^{133}$ In 1920 and 1940, citation to U.K. precedent accounted for $63.7 \%$ and $66 \%$, respectively, of all High Court citations to authority, while citation to Australian courts accounted for only $27.8 \%$ and $20 \%$, respectively. ${ }^{134}$ By contrast, citation to non-U.K., non-Australian courts remained consistently low. Such citations reached a high of $5.8 \%$ of all High Court citations to authority in 1980 , a low of $2.7 \%$ in 1960 , and accounted for $5.4 \%$ in $1996 .{ }^{135}$ Interestingly, with the exception of 1920 , secondary sources consistently accounted for a greater percentage of all High Court citation to authority than citation to non-U.K., nonAustralian precedent. ${ }^{136}$

Between 1903 and 1999, the High Court of Australia cited foreign precedent in an average of $87.7 \%$ of reported cases. ${ }^{137}$ The years 1911 to 1920 saw the lowest percentage of cases citing foreign precedent, ${ }^{138}$ while the years 1961 to 1970 and 1991 to 1999 saw the highest. ${ }^{139}$ During the full period, 1903 to 1999, an average of $15.3 \%$ of High Court cases cited U.S. authority. ${ }^{140}$ By comparison, over the same period an average of $83 \%$ of High Court cases cited U.K. authority, $12.8 \%$ cited

133. Id. at 98-99. As discussed in more length below, one possible explanation (based on temporal correlation) is that until 1986 cases originating in Australia could be appealed to the Privy Council in London, and that this final level of appeal perpetuated reliance on English precedents. Id. at 99.

134. Id. at 98 .

135. Id.

136. Id. The percentages by year are as follows: $1920: 3.8 \%$ (versus $4.7 \%$ foreign courts); 1940: $9 \%$ (versus $4.6 \%$ foreign courts); 1960 : $10.1 \%$ (versus $2.7 \%$ foreign courts); $1980: 7 \%$ (versus 5.8\% foreign courts); 1996: 10.5\% (versus 5.4\% foreign courts). See supra note 132.

137. See Topperwien, supra note 126 , at 281 . This piece does not, for whatever reason, include data for the years 1901-1903, hence the small difference in periods reviewed in this section. The relevant data is reproduced in the table below. Id.

Percentages of High Court Cases in which Foreign Precedents have been Cited

\begin{tabular}{lllllllllll}
\hline Cases from & $1903-$ & $1911-$ & $1921-$ & $1931-$ & $1941-$ & $1951-$ & $1961-$ & $1971-$ & $1981-$ & $1991-$ \\
& $10(\%)$ & $20(\%)$ & $30(\%)$ & $40(\%)$ & $50(\%)$ & $60(\%)$ & $70(\%)$ & $80(\%)$ & $90(\%)$ & $99(\%)$ \\
\hline England & 83 & 70 & 82 & 88 & 78 & 81 & 86 & 89 & 85 & 88 \\
USA & 14 & 10 & 11 & 12 & 10 & 9 & 8 & 13 & 25 & 41 \\
Canada & 4 & 4 & 7 & 7 & 5 & 6 & 6 & 10 & 21 & 37 \\
NZ & 5 & 4 & 7 & 13 & 10 & 8 & 13 & 15 & 20 & 33 \\
$\begin{array}{l}\text { Any } \\
\text { foreign }\end{array}$ & 88 & 75 & 87 & 89 & 91 & 84 & 92 & 91 & 88 & 92 \\
\hline
\end{tabular}

138. See id. During this period, the High Court cited foreign precedents in only $75 \%$ of its cases. $I d$.

139. See id. Both periods saw $92 \%$ of High Court decisions including citation to some foreign precedent. $I d$.

140. See id. 
New Zealand authority, and $10.7 \%$ cited Canadian precedents. ${ }^{141}$ The years 1981 to 1999 show by far the greatest percentage of High Court cases citing U.S. authority: $25 \%$ for 1981 to 1990 and $41 \%$ for 1991 to 1999. ${ }^{142}$

Turning to U.S. citations, between 1901 and 1990 there were a total of 3,858 citations to U.S. authority. The two leading decades of von Nessen's first study by number of U.S. citations were the first, 1901 to 1910 , and the last, 1981 to 1990 , with the latter boasting nearly twice the number of U.S. citations as the former. The decade with the most U.S. citations, 1981 to 1990 , also saw roughly six times as many citations as the decade with the fewest, 1961 to $1970 .{ }^{143}$ During that period, constitutional law cases accounted for the majority of U.S. citations. In fact, there were roughly three times as many constitutional law cases as criminal law cases, the next highest area of law. ${ }^{144}$ The percentage of cases from 1901 to 1990 citing some U.S. authority, broken down by category, are as follows: constitutional law: $54.7 \%$; public law: $8.8 \%$; contracts/commercial: $3.5 \%$; criminal: $5.2 \%$; tort: $5 \%$; other common law: $15.6 \%$; other statutory: $5.5 \%$; miscellaneous: $1.7 \% .{ }^{145}$

Von Nessen's studies also present some anecdotal evidence of the role of the U.S. Supreme Court in the HCA's practice of citing to U.S. authority. For example, von Nessen notes that "[i]nitially, many of the Justices of the High Court (including a number actually involved in the drafting of the Australian Constitution) preferred to embark upon interpretation of a written constitution with guidance from the U.S. Supreme Court, a tribunal with over a century's experience in that

\begin{tabular}{|c|c|c|c|c|c|c|c|c|c|}
\hline \multicolumn{10}{|c|}{ References to United States Cases by the High Court 1901-1990 } \\
\hline Decade & Total & Con & Pub & Comm & Tort & Crim & CL & SL & Misc \\
\hline $1901-1910$ & 565 & 404 & 46 & 23 & 7 & 9 & 22 & 47 & 7 \\
\hline $1911-1920$ & 474 & 341 & 46 & 11 & 22 & 2 & 30 & 16 & 6 \\
\hline $1921-1930$ & 273 & 203 & 6 & 21 & 8 & 0 & 28 & 5 & 2 \\
\hline $1931 \cdot 1940$ & 269 & 130 & 7 & 16 & 36 & 7 & 22 & 45 & 6 \\
\hline $1941 \cdot 1950$ & 366 & 284 & 29 & 6 & 0 & 7 & 16 & 11 & 13 \\
\hline $1951-1960$ & 296 & 190 & 22 & 4 & 42 & 3 & 31 & 3 & 1 \\
\hline $1961-1970$ & 190 & 95 & 14 & 6 & 37 & 8 & 14 & 16 & 0 \\
\hline $1971-1980$ & 329 & 92 & 52 & 12 & 10 & 30 & 90 & 17 & 26 \\
\hline 1981-1990 & 1096 & 370 & 118 & 37 & 31 & 134 & 349 & 53 & 4 \\
\hline Totals & 3,858 & 2,109 & 340 & 136 & 193 & 200 & 602 & 213 & 65 \\
\hline
\end{tabular}

144. See id.

145. Id. at 900 graph 1. 
process." ${ }^{146}$ By the 1920 s, von Nessen notes, this preference shifted, and a majority of the HCA started viewing U.K. interpretive principles as more applicable than U.S. methods. ${ }^{147}$ Other possible reasons for the attitude shift away from the U.S. Supreme Court include differences of opinion regarding changes in the U.S. Supreme Court's views of federalism and the evolution of Commerce Clause jurisprudence during the New Deal era. ${ }^{148}$

\section{b. Trends}

The twentieth century saw changes in the practice and output of the High Court of Australia that had a noticeable impact on the HCA's practice of citing foreign law. Except for citations to U.K. law, which remained relatively stable over the century, ${ }^{149}$ High Court citation to U.S., New Zealand, and Canadian precedents all increased substantially beginning in the $1970 \mathrm{~s}$ and continuing until 1999.150 U.S. citations appeared in 14\% of High Court cases between 1903 and 1910, dipping to $9 \%$ between 1951 and 1960 , rising to $13 \%$ between 1971 and 1980 , then spiking to $25 \%$ between 1981 and 1990 , and $41 \%$ between 1991 and 1999. ${ }^{151}$ By comparison, citations to Canadian and New Zealand authorities followed a slightly different, though consistently upward trend, beginning low (4\% and 5\% respectively) from 1903 to 1910 , and gradually increasing between 1911 and 1980, before spiking in the years 1981 to 1990 (21\% and 20\% respectively) and 1991 to 1999 (37\% and $33 \%$ respectively). ${ }^{152}$

Turning to U.S. precedents in particular, von Nessen's second study shows that HCA citation to U.S. precedent varied quite a bit in terms of the volume and area of law between 1901 and $2002 .{ }^{153}$ Even so, a significant majority of the cases citing U.S. authority were categorized as constitutional law cases. Because the U.S. Constitution provided a model for parts of the Australian Constitution, it is unsurprising that the HCA would seek to learn from U.S. constitutional jurisprudence to better understand certain Australian constitutional provisions. ${ }^{154}$

146. Id. at 908.

147. See id.

148. Id. at 908-09.

149. See Topperwien, supra note 126 , at 281 tbl.1.

150. See id. Table 1 only provides data up to 1999 .

151. Id.

152. See id.

153. See von Nessen, Australian Experience, supra note 128, at 899.

154. Id. at 904 . 
Von Nessen's first study found a significant increase in the number of citations to U.S. authority beginning in 1971.155 This upward trend reached a high water mark between 1981 and 1990.156 One explanation is that between 1975 and 1985, appeals to the Privy Council in London ceased entirely, leaving the HCA as the final level of appeal for all cases in Australia. ${ }^{157}$ This shift enabled greater judicial independence and might explain the increase in the citation to U.S. precedent overall. ${ }^{158} \mathrm{In}$ addition, it is important to note that the increased caseload of the HCA "would, consequently, be a contributing factor in relation to increased use of United States cases."159

Although the HCA most often cited U.S. authority in constitutional law cases, "[t]he relative predomination of constitutional issues in the early decades was replaced in later years with a broadening range of legal areas." 160 This change occurred within a larger trend of citation to U.S. precedent, which declined twenty years after the enactment of Australia's Constitution in 1920, and then increased in the late twentieth century. ${ }^{161}$ Reflecting both the larger trend and the decline in the number of constitutional issues, the percentage of constitutional law cases in which the HCA cited U.S. authority dropped from $71.5 \%$ to $33.7 \%$ between the first and last decade of the first von Nessen study. ${ }^{162}$ Further, from 1991 to $2002,35.3 \%$ of the U.S. precedents cited were constitutional law cases, while the number of common law and statutory law cases continued to rise, even as compared to the last period of the study. ${ }^{163}$ One explanation for this trend is that the HCA used U.S. precedents as a starting point but gradually shifted to using domestic precedents once these became established. ${ }^{164}$ This explanation, however, does not fully account for what von Nessen describes as "a sudden reduction in the use of United States cases" between the 1920s and 1990s. ${ }^{165}$

155. See von Nessen, American Precedents, supra note 55, at 194.

156. See von Nessen, Australian Experience, supra note 128, at 891 tbl.1.

157. Id. at 913-14.

158. Id. As von Nessen discusses, the termination of appeals to the U.K. Privy Council occurred in two phases: first, appeals from the High Court to the Privy Council itself ended in 1975, but appeals from state supreme courts continued; second, by 1986, appeals from state courts to the Privy Council ended. See id. at 913.

159. Id. at 898-99.

160. Id. at 899 .

161. See id. at 901 graph 2.

162. Id. at 902 .

163. Id. at 919-20; see also id. at 919 (tbl. of topics).

164. Id. at 907 .

165. Id. at 908 . 
Far from an aberration, the significant uptick in HCA citation to U.S. precedent, noted at the end of von Nessen 1, continued through the period reviewed in von Nessen 2.166 Between 1991 and 2000, the HCA cited U.S. authority roughly 211 times per year, and roughly 310 times per year between 2001 and 2002.167 By contrast, the HCA cited U.S. precedents an average of 109 times annually between 1981 and 1990, and roughly fifty-six times annually from 1901 to 1910 , the two highest decades in the initial von Nessen period of study. ${ }^{168}$

Thus, as of 2002, there appeared to be a steady upward trend in the number of U.S. court decisions cited by the HCA. 169 This trend appears related to the HCA's increasing consideration of U.S. authority in a growing range of legal areas. For example, the HCA's citation to U.S. precedent increased in cases touching on human rights and international obligations, as well as common law doctrines of contracts and torts. ${ }^{170}$ Two reasons suggested for this development are the end of Privy Council appeals from Australia, and the increased willingness of the HCA to cite foreign precedent.171 In addition, the $\mathrm{HCA}$ recently began deciding cases based on rights it has found implied in the language of the Australian Constitution. ${ }^{172}$ Because, as previously mentioned, the Australian Constitution is based on elements of the U.S. Constitution, the HCA might find U.S. constitutional cases newly relevant, and therefore cite to them. ${ }^{173}$

\section{c. Other Explanations and Conclusions}

As shown above, the High Court of Australia's citation to U.S. authority constitutes only a small percentage of its total number of citations to authority. Citation to foreign courts (excluding U.K. courts) has never accounted for even as much as $6 \%$ of total citations by the HCA, ${ }^{174}$ and that includes citations to all other foreign countries, including the United States, Canada, New Zealand, and other common

166. See supra, note 128.

167. See von Nessen, Australian Experience, supra note 128 at 917-18.

168. Id. at 918 . See also id. 918 graph 6.

169. Id. at 919 tbl. of topics.

170. Id. at 921 .

171. Id.

172. Id. at 922 .

173. See id.

174. See Smyth, supra note 127 , at 98. 
law countries. ${ }^{175}$ In absolute numbers, the HCA has cited secondary sources significantly more than it has cited U.S. authority. ${ }^{176}$

One explanation for the infrequent citation to U.S. authority is that citation practices depend on the historical, social, and cultural milieu described by Justice Greaney. ${ }^{177}$ For example, the decrease in references to U.S. precedents beginning in the 1920 s is arguably a result of the HCA's determination that Australian legal culture is "more appropriately guided by British than by United States practice."178 Likewise, it is plausible that the HCA rarely cited U.S. authority prior to the $1970 \mathrm{~s}$, in part, because of differing views on the role of the judiciary. ${ }^{179}$ Furthermore, the disregard for U.S. constitutional precedent during the early and mid-twentieth century arguably resulted from differing views about federalism and the relative power of the national government, which greatly increased during the New Deal era. 180

Indeed, such considerations also provide a plausible explanation for the differing rates of citation to U.S. authority in each area of law. For example, one reason for the lower incidence of common law and statutory cases citing U.S. authority is that historical and structural considerations rendered U.S. case law unhelpful to the HCA. ${ }^{181}$ Regarding the common law, for much of the period studied, the HCA could not diverge significantly from U.K. law because of the possibility of appeal to the Privy Council. ${ }^{182}$ Regarding statutory cases, the HCA generally went in a different direction than U.S. courts for a variety of reasons. Prior to the mid-1970s, Australia borrowed little from U.S. legislative models, rendering U.S. authority on statutory issues of little help to the HCA. ${ }^{183}$ Additionally, prior to 1981, Australian courts were inclined to strictly construe legislative acts, and the HCA did not consider the same range of constitutional issues, like those in the U.S. Bill of Rights, in adjudicating statutory cases. ${ }^{184}$

175. Topperwien, supra note 126 , at 281 .

176. This inference can be drawn by considering the data noted by both Smyth and Topperwien. See Smyth, supra note 127, at 98; Topperwien, supra note 126, at 281.

177. See supra Part I.A.1.

178. von Nessen, Australian Experience, supra note 128, at 913. See also Smyth, supra note 130 , at 98 (noting that English courts in aggregate were cited more, in absolute numbers, than even Australian courts).

179. von Nessen, Australian Experience, supra note 128, at 913.

180. See id.

181. See id. at 906-07.

182. Id. at 906 .

183. Id. at 907 .

184. Id. 
Von Nessen suggests that the increased citation to U.S. precedent beginning in the late twentieth century is a result of the HCA's comparative impulse, rather than the novelty of certain legal questions. This argument is based on the recognition that "as globally common issues arise, consideration of the broadest range of potential solutions and approaches to these common problems is not only permissible, but advisable." 185 In his view, the data "is consistent with the conclusion that the High Court now accepts the value of a global perspective, and that this sustains the increased use of United States authority." 186 Whatever the reason underlying the clear upward trend in HCA citation to U.S. authority, the data cuts against claims of a diminishing influence of U.S. authority among foreign jurists.

\section{Loose ends}

High courts of other nations frequently cite U.S. judicial decisions, at least in relative terms. However, the overall practice of citing foreign authority is fairly limited. This is true even in countries that, for reasons of history, proximity, and constitutional similarities, might seem logically predisposed to cite U.S. precedents. As the studies of Canadian citation to U.S. precedent show, "the diffusion of citations [to U.S. courts does not] fit particularly well with the overtones of the 'emerging judicial community' literature." 187 And, as noted in the discussion of Australian citation, even secondary sources are more frequently cited than cases from non-U.K. foreign courts, let alone just U.S. courts. ${ }^{188}$

That being said, within the relatively small sliver of citations to foreign precedent in both Canada and Australia, U.S. authority is second only to U.K. authority in citation frequency. ${ }^{189}$ Thus, there is clearly merit to observations that the United States is an "exporter" of jurisprudence and jurisprudential ideas, 190 as well as to claims that the U.S. Supreme Court wields some measure of influence on national courts in other countries. ${ }^{191}$ Based on the SCC and HCA citation analysis discussed in this note, claims that U.S. jurisprudential

185. Id. at 922 .

186. Id.

187. McCormick 2, supra note 24 , at 105.

188. See Smyth, supra note 127 , at 98.

189. See supra Parts I.B.1.a, I.B.2.a.

190. See, e.g., Louis Henkin, Introduction to ConSTITUTIONALISM AND RIGHTS: THE INFLUENCE OF THE UNITED STATES CONSTITUTION ABROAD, supra note 62, at 1-15.

191. See, e.g., Liptak, supra note 1. 
influence is waning seems speculative or anecdotal, rather than data driven.

As noted above, the relative influence (measured by citation analysis) of U.S. authority, and the U.S. Supreme Court in particular, on the Supreme Court of Canada has recently declined. At the same time, the data available regarding the citation practices of the High Court of Australia indicate that citation to U.S. authority in general is increasing. A review of how U.S. authority is used, as opposed to how often, will help determine the full extent of the influence the U.S. Supreme Court wields abroad, as well as any changes to it over time. Unfortunately, available studies of "how" are less thorough than the studies of "how often."192

\section{Informal Judicial Meetings and Exchanges}

Though important, empirical study alone is insufficient to fully capture the U.S. Supreme Court's influence abroad. Advances in telecommunications have placed many court decisions at the fingertips of judges the world over, enabling a curious jurist to access decisions almost as soon as they are released. ${ }^{193}$

Beyond technology, it is also important to consider the "informal" contacts-i.e. interactions beyond the context of adjudicating casesbetween U.S. Supreme Court Justices and their colleagues and counterparts around the world. In addition to occasionally citing the opinions of their colleagues, "[j] udges are also meeting face to face"194 and "are getting to know each other better as they interact at conferences and in personal meetings. . . "195 These informal contacts between judges provide opportunities for judges to engage in dialogue aside from citation of foreign law, undermining claims that the U.S. Supreme Court is "out of step" with the transnational judicial dialogue. ${ }^{196}$ Anne-Marie Slaughter has expertly catalogued many

192. See, e.g., Bushnell, supra note 81, at 161-63 tbl.3 (breaking down SCC citations into five classifications: Used, Same, Qualified, Special, Differ. By far the most predominant category is that of "Used" - "[t]he characteristic of this category is that there is nothing in the judgment to indicate that anything out of the ordinary is happening. Cases from the United States appear to be used as the judge would use any case he considered an authority."); see also McCormick 2, supra note 24, at 114-25 (including a review of how U.S. authority is used in specific cases; however, this review lacks the same level of thoroughness as McCormick's empirical studies of citations).

193. See footnote text supra note 114 (discussing electronic databases, and providing some examples of internet-based legal resources and courts posting their decisions online).

194. Slaughter, supra note 5, at 1120.

195. McCormick 2, supra note 24, at 105.

196. See supra note 8 , and accompanying text. 
examples of such contacts, 197 and the following merely supplements her valuable work.

Slaughter observes that judges around the world are meeting at inter-judicial conferences, ${ }^{198}$ via judicial exchanges, ${ }^{199}$ and through conferences sponsored by law schools and NGOs. ${ }^{200}$ One prominent example is the gathering of the Organization of Supreme Courts of the Americas (OSCA), hosted in Washington, D.C. in 1995. Chaired by thenChief Justice William Rehnquist, the meeting boasted attendees from twenty-five countries representing North America, Central America, South America, and the Caribbean. ${ }^{201}$ Some of these experiences have been noted in judicial opinions. ${ }^{202}$ In addition, "[a] flood of foundation and government funding for judicial seminars, training programs, and

197. See Slaughter, supra note 5, at 1120-23.

198. Id. at 1121. Some conferences have even spawned publications intended to facilitate transnational judicial dialogue on specific issues. For example, the Hague Conference on Private International Law (HCCH) publishes a semi-regular newsletter titled The Judge's Newsletter on International Child Protection. HCCH PuBliCATIONS, http://www.hcch.net/index_en.php?act=publications.listing\&sub=5 (last visited Jan. 9, 2011) (providing a free archive of published newsletters).

199. Id. at 1118-20. See also William H. Rehnquist, Remarks of the Chief Justice at the Court of Appeals for the Federal Circuit 20th Anniversary Judicial Conference (Apr. 8, 2002), http://www.supremecourt.gov/publicinfo/speeches/viewspeeches.aspx?Filename $=$ sp_ 04-08-02a.html (discussing the efforts of the International Judicial Relations Committee of the Judicial Conference, and commenting on numerous international exchanges he had participated in with countries such as Russia, Canada, Mexico, India, Germany, and others).

200. Slaughter, supra note 5, at 1121-22. See also Michel Rosenfeld, Justices at Work: An Introduction 18 CARDOZo L. REV. 1609 (1997) (reviewing a day-long conference, held at the Cardozo Law School on September 19, 1995, that brought together judges and constitutional scholars from seven countries to adjudicate a Moot Court competition. Among the participants, Justice Ruth Bader Ginsburg of the U.S. Supreme Court); Ami Eden, Bork Turns Kagan Process into Fight over Israeli Justice, JEWISH TELEGRAPHIC AGENCY, June 29, 2010, http://jta.org/news/article/2010/06/29/2739826/bork-turns-kaganprocess-into-fight-over-israeli-justice (noting Justice Scalia's introduction of Israel Supreme Court Chief Justice Aharon Barak at the March 2007 meeting of the American Association of Jewish Lawyers and Jurists). For a seemingly exhaustive list of various international judicial organizations and conferences, as well as an extensive list of international judicial seminars and similar efforts, see HAGUE INST. FOR THE INTERNATIONALISATION OF LAW [HIIL], INVENTORY AND BIBLIOGRAPHY CONFERENCE CONCEPT PAPER AND OUTLINE OF WORKSHOPS app. A (2008), http://ssrn.com/abstract=1511143 (prepared for the Hiil Law of the Future Conference: The Changing Role of Highest Courts in an Internationalising World, Oct. 23-24, 2008).

201. See Justices, Judges from Across Western Hemisphere Assemble, Create Charter for New Organization of Supreme Courts, INT'L JUD. OBSERVER, Jan. 1996, at 1, 1, available at http://www.fjc.gov/public/pdf.nsf/lookup/intobs02.pdf/\$File/intobs02.pdf. See generally 40 ST. LoUIS U. L.J. 969 (1996) (the entire issue is dedicated to publication of the OSCA 1995 conference proceedings).

202. E.g., McCreary County, Ky. v. ACLU, 545 U.S. 844, 885 (Scalia, J., dissenting) 
educational materials under the banner [of] 'rule of law' programs has significantly expanded the opportunities for cross-fertilization." 203 Furthermore, U.S. Supreme Court Justices have given at least seven speeches in four countries over the last ten years. ${ }^{204}$ Some Justices have engaged in literary projects with counterparts from abroad,205 and the Court has paid tribute to fallen colleagues abroad. ${ }^{206}$

\section{II. (BIG) "GRAINS OF SALT"}

While not exhaustive, the data available from citation analysis challenges the view that the U.S. Supreme Court wields diminished influence abroad. That view appears to be largely based on anecdotal evidence, and the preceding sections are intended to provide some much-needed context in which to accurately assess these assertions. By focusing on measurable indicators and accounting for more intangible avenues of influence and exchange, the foregoing has shed some light on what influence the U.S. Supreme Court actually wields in the emerging global judicial community. This Note has reviewed the frequency of citation to U.S. precedent in Canada and Australia and placed that data in perspective vis-à-vis frequency of citation to both foreign and municipal precedent. In addition, the discussion presented an overview of the various activities the Justices of the U.S. Supreme Court engage in that place them in contact with counterparts and colleagues across the globe.

Regarding the contention of waning Supreme Court influence abroad, an analysis of actual citation practice undermines the validity of its contenders' anecdotal evidence. As noted, in absolute numbers the citation to foreign precedent by the SCC and HCA represents only a fraction of the total number of citations to judicial authority employed by these two courts. Thus, any measurable influence occurs within a relatively minor segment of the jurisprudence of these courts, and even then the data does not necessitate the conclusion that U.S. influence is waning. Indeed, in the case of Australia, the number of citations to U.S. authority trends up.

203. Slaughter, supra note 5 , at 1117.

204. Speeches, Supreme Court of the United States, http://www.supremecourt.gov/ publicinfo/speeches/speeches.aspx (last visited Aug. 29, 2010).

205. E.g., William Creeley, Book Note, $A$ Useful Conversation, 80 N.Y.U.L. REV. 694 (2005) (reviewing JUDGES IN CONTEMPORARY DEMOCRACY: AN INTERNATIONAL CONVERSATION (Robert Badinter \& Stephen Breyer eds., 2004)).

206. See, e.g., Justices, Law Enforcement Officials Pay Tribute to Assassinated Italian Judge, The BLT: The Blog of Legal Times, Oct. 29, 2009, http://legaltimes.typepad.com/ blt/2009/10/justices-law-enforcement-officials-pay-tribute-to-assassinated-italianjudge.html (last visited Nov. 20, 2009). 
Citation to U.S. authority by the SCC remained fairly consistent from 1945 to 2008 , and citation to U.S. authority trended up between 1945 and 1994. The fact that SCC citation to U.S. Supreme Court authority most frequently referred to decisions of the Warren and Burger Courts undermines claims that citation to the U.S. Supreme Court has diminished because of political differences over the last decade. Nor does the SCC's slight decrease in U.S. Supreme Court citations and slight increase in U.S. state court citations necessarily speak to a diminishing influence of the U.S. Supreme Court. This is especially true in light of changes in the type of cases appearing on the SCC's docket.

One could reasonably conclude that changes in citation to the U.S. Supreme Court are a result of municipal law maturing to the point at which continued reference to foreign authority, whether from the United States or elsewhere, is less helpful than reliance on domestic precedent. ${ }^{207}$ Such an inference does not necessarily speak to a diminishing influence, at least no more so than it speaks to a diminishing need for direct reliance on foreign authority to decide cases involving established legal principles. Perhaps if citation to foreign authority were shown to increase, but citation to the U.S. Supreme Court dropped off in favor of other non-municipal authority, the claims of diminishing influence would appear more credible. That is not the case at present, at least with regard to the U.S. Supreme Court's influence on Canadian jurisprudence. Rather, concluding that municipal jurists have simply opted for established domestic authority over foreign decisions may even speak to a lasting influence, if the domestic principles were initially derived from foreign sources.

The data pertaining to Australia cut more strikingly against the claims of diminishing influence. Citation to U.S. authority, and the U.S. Supreme Court in particular, represents a small segment of the HCA's overall citation. Indeed, citation to non-municipal authority other than U.K. decisions has been consistently outpaced by citation to secondary sources. For example, in 1996 citation to secondary sources accounted for $10.5 \%$ of all citations by the HCA, as compared to citation to nonU.K. foreign authority accounting for only $5.4 \%$.

Yet within this small segment of HCA citation, the data reflects a possible increase in U.S. influence. Unlike the citation practice of the SCC, the HCA demonstrated an upward trend in the citation to U.S. authority. With the exception of the decade 1951 to 1960 , the percent of cases citing U.S. authority trends up, peaking at $41 \%$ in the decade 1991

207. See, e.g., McCormick 2, supra note 24, at 129 ("The real story of the evolution of Canadian jurisprudence is its steadily increasing focus on domestic judicial authority, especially that of the Supreme Court itself, and not on foreign sources."). 
to 1999 . And citation to U.S. authority increased to 310 citations per year for 2001 to 2002 from the average of 211 citations per year for 1991 to 2000. By comparison, the percent of cases citing authority from Canada and New Zealand also trend upward over the twentieth century. Far from supporting assertions of diminishing influence, the data points in the opposite direction: that of increasing relevance, if not influence, of the U.S. Supreme Court at a time when the HCA was increasingly open to the use of foreign authority. The fact that HCA citation to U.S. authority spread to additional legal areas at the same time the frequency of citation increased further supports an inference of increased relevance and influence.

There are other reasons, in addition to the conclusions drawn from the data above, that counsel skepticism of claims that the U.S. Supreme Court is losing its influence. While this paper has focused on citation analysis as a verifiable metric to use in assessing the relative influence of the U.S. Supreme Court, citation analysis alone may not account for the full picture. Influence may come from conversations at conferences, speaking engagements, and through non-judicial projects. ${ }^{208}$ Influence might also come from simply staying current with jurisprudential developments abroad. Indeed, despite disagreeing about citing foreign law in opinions, Justices Breyer and Scalia agree on the potential utility of keeping informed of the decisions of other national and constitutional courts. ${ }^{209}$

Also, given the small number of citations under discussion, and the views professed by Justices and academics advocating comparativism, the precise nature of the Court's influence is ambiguous. To be sure, any precedent considered will have some measure of influence, even if only serving as background. But given the overall context of the comparative exercise and the manner in which foreign precedent is apparently used, precisely what influence the U.S. Supreme Court is supposed to be losing is unclear. To hear the Justices of the SCC and HCA discuss their use of foreign authority, 210 or to consider Justice Breyer's views of appropriate use of comparative materials, ${ }^{211}$ one wonders what it was

208. As noted above, Slaughter, one of the more prolific writers on the subject of the emerging global judicial community, has accounted for this variable in some detail. See Slaughter, Judicial Globalization, supra note 5, at 1120-23.

209. Conversation Between Scalia \& Breyer, supra note 35, at 534 (responding to Justice Breyer's comment that it was not unreasonable to seek to learn how other, similarly situated courts had addressed particular issues, Justice Scalia said, "I'm not preventing you from reading these cases . . I mean, go ahead and indulge your curiosity! Just don't put it in your opinions!").

210. See generally L’Heureux-Dubé, supra note 13 (SCC Justice); La Forest, supra note 64 (SCC Justice).

211. See Conversation Between Scalia \& Breyer, supra note 35, at 541. 
the United States was exporting. ${ }^{212}$ Rather than actual jurisprudence, ${ }^{213}$ perhaps it was a model of constitutionalism. ${ }^{214}$ If so, then it is difficult to see how U.S. influence diminishes by the exercise of a uniquely American contribution-judicial review ${ }^{215}$-merely because others do not routinely consult the results.

If the influence of the U.S. Supreme Court is waning, there are explanations for the phenomenon that are not tied to the Court's apparent hostility to citing foreign authority. As noted by Justice Greaney, law almost always emerges from a specific context, and this background shapes the ways in which courts apply the law to the cases before them.216 Such a view could explain some of the ebb and flow of U.S. Supreme Court citations in foreign courts over time. For example, when facing novel constitutional cases, a court might be more inclined to look abroad to more experienced tribunals for guidance. One would anticipate an increase in the citation to the U.S. Supreme Court when addressing novel constitutional instruments or issues, and that such citations would recede in favor of reliance on domestic precedent once it is established. Smithey arrived at this conclusion in her analysis of the citation practices of Canadian and South African high courts. ${ }^{217}$ And, as discussed above, Bushnell suggests a similar explanation for the relatively high frequency of U.S. citations early in the SCC's history. ${ }^{218}$

The general trends in citation to U.S. precedent abroad could also be considered a reflection of historical developments. For instance, Bushnell argues compellingly that the early willingness to rely on U.S. precedent by the SCC may have resulted from the prevailing view of the common law at the time. ${ }^{219}$ Von Nessen highlights as a turning point

212. But compare Slaughter's contention that constitutional law used to be an export in Liptak, supra note 1 (quoting Anne-Marie Slaughter).

213. "Jurisprudence" here means decisions, opinions, and judicial analysis. As noted above, even advocates of comparative practice do not argue for wholesale adoption of foreign decisions.

214. See Martin Shapiro, The Globalization of Law, 1 IND. J. GLOBAL LeGaL STUD. 37, 48 (1993) ("American constitutional experience . . . has appeared to be singularly innovative and successful and thus serves as a world model.").

215. See generally William R Casto, James Iredell and the American Origins of Judicial Review, 27 CONN. L. REV. 329 (1995) (describing early conceptions of judicial review during the Founding era).

216. Greaney, supra note 50 , at 145 . Justice Scalia made a similar observation, noting that "[o]ne of the difficulties of using foreign law is that you don't understand what the surrounding jurisprudence is." Conversation Between Scalia \& Breyer, supra note 35, at 528.

217. Smithey, supra note 61, at 1199 ("[T] $]$ here is . . . a decline in reliance on foreign sources as time passes and the availability of indigenous constitutional precedent increases.").

218. See supra note 102 and accompanying text.

219. See supra note 102 and accompanying text. 
the determination by the HCA that Australian jurisprudence was more similar to, and therefore better guided by, U.K. courts than by U.S. courts. ${ }^{220}$ And McCormick contends that the sharp increase in citation to U.S. precedent in the 1990 s validates authors who projected that the enactment of the Canadian Charter of Rights and Freedoms would be accompanied by an increased reliance on U.S. Supreme Court jurisprudence. ${ }^{221}$

Similarly, skepticism should extend to assertions that the United States risks lagging behind global jurisprudence by failing to partake in the transnational judicial dialogue happening via citation. While the Justices of the U.S. Supreme Court may presently debate the merits of comparative jurisprudence, the history depicted by Calabresi and Zimdahl clearly demonstrates that citation to foreign authority is not alien to the U.S. Supreme Court. And there is clearly another level of interaction between the Justices and their counterparts abroad beyond citation. Examples include the apparent interest in remaining informed of the jurisprudential developments in other countries, participation in formal judicial conferences, international judicial organizations, speaking engagements, and literary ventures. The number and variety of these activities makes clear that the Justices of the Supreme Court are taking an active role in at least some elements of the emerging judicial community. Thus, the risk of lagging behind may be exaggerated.

In sum, when one looks past the anecdotal evidence and considers the verifiable metric of citation analysis, one finds good reason to approach the claims of Choudhry, Ginsburg, Justice Kirby, Justice LHeureux-Dubé, Lefler, Slaughter, and others with skepticism. Although not conducted here, a review of other national and constitutional courts' citation practices could prove illuminating as to what influence is wielded by the U.S. Supreme Court. In particular, citation analysis of the courts of countries such as Germany and Israel, with legal systems embracing judicial review while not being rooted entirely in common law, might prove particularly useful. Furthermore, there are other plausible explanations for trends in citation to the U.S. Supreme Court, and U.S. courts overall, that do not herald a decline in influence. Although not sufficient to dismiss claims of declining influence outright, the citation analysis and alternative explanations addressed in this note provide ample reason to seek additional data before drawing conclusions about the influence of the U.S. Supreme Court abroad.

220. See supra note 177 and accompanying text.

221. See, e.g., Christopher P. Manfredi, The Use of United States Decisions by the Supreme Court of Canada Under the Charter of Rights and Freedoms, 23 CAN. J. POL. SCI. 499, 499-500 (1990). 